\title{
Cachet Dosage Form
}

National Cancer Institute

\section{Source}

National Cancer Institute. Cachet Dosage Form. NCI Thesaurus. Code C64878.

A solid composed of dry powdered active and/or inert ing redient(s) covered by an edible shell. The shell consists of two concave pieces of wafer made of flour and water. 